\title{
Folic acid fortification and public health: Report on threshold doses above which unmetabolised folic acid appear in serum Mary Rose Sweeney*1,3, Joseph McPartlin ${ }^{1}$ and John Scott ${ }^{2}$
}

Address: ${ }^{1}$ From the Department of Clinical Medicine, Trinity College, Dublin, Ireland, ${ }^{2}$ Department of Biochemistry, Trinity College, Dublin, Ireland and ${ }^{3}$ UCD School of Public Health Population Science, University College Dublin, Dublin, Ireland

Email: Mary Rose Sweeney* - maryrose.sweeney@ucd.ie; Joseph McPartlin - jmcprtln@tcd.ie; John Scott - jscott@tcd.ie

* Corresponding author

Published: 22 March 2007

BMC Public Health 2007, 7:4I doi:10.1 |86/|47|-2458-7-4|
Received: 7 July 2006

Accepted: 22 March 2007

This article is available from: http://www.biomedcentral.com/I47I-2458/7/4I

(c) 2007 Sweeney et al; licensee BioMed Central Ltd.

This is an Open Access article distributed under the terms of the Creative Commons Attribution License (http://creativecommons.org/licenses/by/2.0), which permits unrestricted use, distribution, and reproduction in any medium, provided the original work is properly cited.

\begin{abstract}
Background: All flour in the USA is fortified with folic acid at a level of $140 \mu \mathrm{g} / 100 \mathrm{~g}$ which is estimated to supply an extra $100 \mu \mathrm{g}$ daily to the average diet. Some researchers have advocated that this be increased to double and even four times this amount. Based on previous research these higher levels are likely to lead to the appearance of unmetabolised vitamin in the circulation, which may have safety implications for sub-groups of the population. The UK and the Republic of Ireland will likely introduce mandatory fortification also in the next year or so.

The aim of this study was to capture the short-term effect of folic acid fortification on unmetabolised folic acid in serum after chronic consumption of folic acid.

Methods: After pre-saturation with $400 \mu \mathrm{g}$ folic acid supplements daily for 14-weeks, healthy folate replete adults $(n=20)$ consumed folic acid fortified bread, at three different levels $(400 \mu \mathrm{g}$, $200 \mu \mathrm{g}, 100 \mu \mathrm{g}$ ) over a period of one week each. The dose was administered in two-equal sized slices consumed at $09.00 \mathrm{hrs}$ and $13.00 \mathrm{hrs}$. Serum samples for total folate and folic acid were collected at baseline, after I4-weeks of supplementation, and pre and post (at I, 2, 3 and 4 hours) each dose tested.

Results: Unmetabolised folic acid was detected after the 14-week supplementation period. Folic acid was not detected in either the $200 \mu \mathrm{g}$ or $100 \mu \mathrm{g}$ (current US regime) doses tested but was present at the highest level $(400 \mu \mathrm{g})$ tested.

Conclusion: Our findings suggest that persons exposed to the current US fortification programme supplying an average of $100 \mu \mathrm{g}$ per day or less are unlikely to have unmetabolised folic acid in serum. It also seems that daily consumption of the higher level of $200 \mu \mathrm{g}$ or less is unlikely to be problematic. Increasing the level however to $400 \mu \mathrm{g}$ on the other hand is likely to lead to unmetabolised folic acid appearance.
\end{abstract}

\section{Background}

To prevent Neural Tube Defects (NTDs) the Food and Drug Administration (FDA), USA implemented mandatory folic acid fortification of flour. This commenced in
January 1998. The fortification level was set at $140 \mu \mathrm{g} / 100$ g flour supplying 100 $\mu \mathrm{g}$ daily to the average American. This amount was selected on the basis that it would not result in intakes in excess of $1 \mathrm{mg}$ (upper safe daily limit) 
by any population group. Doubt has been cast on the actual level of fortification however and recent calculations have shown that the level of folic acid fortification is likely to have been over twice the amount mandated [1] with average intakes ranging from 215 to $240 \mu \mathrm{g} /$ day.

The Centers for Disease Control (CDC) supported the fortification strategy but because this level fell short of the target to supply $400 \mu \mathrm{g}$ to all women of childbearing age, they considered increasing the level to $350 \mu \mathrm{g}$ and even $700 \mu \mathrm{g} / 100 \mathrm{~g}$, which would supply approximately 2.5 and 5 times more folic acid respectively [2] The primary concern with these higher levels of fortification is that certain segments of the population will be exposed to amounts of folic acid greater than $1000 \mu \mathrm{g} /$ day and that this may have adverse effects.

After much deliberation by the relevant authorities in the UK folic acid will be added to bread in the UK within a year. In addition the Republic of Ireland have opted for mandatory fortification, which will be fully implemented in the next year.

Research to date suggests that the enzymatic reduction and methylation of folic acid during its absorption in the intestine or its first pass through the liver is dose-dependent. Hence oral folic acid above certain threshold doses saturates the normal intestinal absorptive mechanisms and results in unmetabolised folic acid in serum as well as the normal metabolite 5-methyltetrahydrofolate. This has been demonstrated at oral doses in the region of $200 \mu \mathrm{g}$ [3] and $266 \mu \mathrm{g}$ [4]. In a more recent paper it was shown that repeated consumption of physiological amounts of folic acid lead to the accumulation of unmetabolised folic acid in serum [5]. It has also been demonstrated that passive consumption of folic acid in foodstuffs by pregnant women leads to the appearance of unmetabolised folic acid in foetal cord blood [6]. While these studies examined the acute serum response to folic acid, none have investigated the effect after a prolonged period of exposure to the vitamin.

Folic acid has the potential to mask the early haematological manifestations of pernicious anaemia. This has been demonstrated experimentally [7-10] and clinically [1115]. Other safety considerations of excess folic acid consumption highlighted by the FDA [16] include potential unknown risks for pregnant women, and persons on antiepileptic and anti-folate medication. The FDA also noted the uncertainties regarding the effects of chronic exposure in children, whose requirements for folate are lower than those of adults. Furthermore evidenced based $[17,18]$ and hypothetical concerns include the potential to promote cancer $[19,20]$ and the recent hypothesis that exposure of the foetus to excess folic acid may favour the selection of the Methylentetrahydrofolate polymorphism, associated with a range of debilitating illnesses [21].

To date no studies have examined the effect of long-term consumption of folic acid on unmetabolised folic acid in serum. The accumulation of folic acid after consumption of fortified bread repeatedly over only one 8-hour period [5] provides justification for this. In this paper we examined unmetabolised folic acid appearance after consumption of folic acid for a prolonged period. The three levels selected to be tested were in the region of that already implemented in the mandatory US fortification programme and the two higher levels considered by the CDC.

\section{Methods \\ Fortification of bread}

3 batches of bread were made specifically for the study by Superquinn Bakeries Kimmage, Dublin, under the supervision of the principal researcher. Batch 1 supplied $50 \mu \mathrm{g}$ per slice, batch 2 supplied $100 \mu \mathrm{g}$ per slice and batch 3 supplied $200 \mu \mathrm{g}$ per slice. Each slice weighed about $30 \mathrm{~g}$. The folic acid was added to water, which was then mixed with the flour and other dry ingredients. The dough was formed by thorough mixing with an industrial mixer. The bread was then baked under normal conditions and stored in a food freezer at $-20^{\circ} \mathrm{C}$ until eaten (approximately 2-6 weeks in total). Preliminary research by the researcher showed that folic acid does not degrade under these conditions [22].

\section{Participants}

20 healthy adult subjects, 10 females and 10 males, aged 20-40 years of age were recruited by voluntary participation from the student and staff population of the Central Pathology laboratory, St. James's Hospital, Dublin and from the general population. Ethical approval was obtained from the Ethics Committee of the Federated Dublin Voluntary Hospital, James's Street, Dublin. After informed consent from all participants a medical history was taken and all subjects were found to be free of vascular, hepatic, renal or gastrointestinal disease. Oral contraceptive pill users were excluded from participating, as were those taking multi-vitamin preparations or anti-convulsant therapy. One subject dropped out of the study for personal reasons. 19 subjects completed the study.

\section{Intervention-phase I}

For clarity a flow diagram illustrating diagrammatically the interventions and sampling points is included (figure 1). After confirming that all subjects were folate replete at recruitment by performing red cell and serum folate measurements (table 1) subjects were instructed to consume one $400 \mu \mathrm{g}$ folic acid supplement daily for 14 weeks. The rationale for this regime was to saturate the subjects at the highest level of fortification to be tested in the study. From 
previous research [23] we knew it takes 14-weeks to reach a serum folate plateau at this dose. Baseline serum unmetabolised folic acid concentrations were also established (table 1). Subjects were issued with folic acid supplements (Clonfolic $400 \mu \mathrm{g}$ ) and were instructed to omit all other sources of folic acid either in supplemental from or in fortified foods for the duration of the study. A list of commercially available folic acid fortified foodstuffs as well as single/multivitamin preparations containing folic acid on the Irish market was issued to each subject. A list of suitable non-fortified substitutes was issued and subjects were reimbursed financially for these products in order to improve compliance. Subjects were contacted weekly either by telephone or in person throughout the duration of the study to enhance and improve motivation.

Serum samples were collected for red cell, serum folate and unmetabolised folic acid at week 10 and week 14 post-supplementation. At both of these time-points samples were collected 6-hours after the vitamin had last been consumed to allow time for the acute post-prandial folic acid to clear from the circulation.

\section{Intervention-phase II}

Week I

After the 14-week supplementation period bread was administered to subjects (Regime $C$ ) supplying a total of $400 \mu \mathrm{g}$ of folic acid in 2 slices over a period of 7 days. The $1^{\text {st }}$ slice was consumed each day at breakfast time $(09.00$ hrs) and the $2^{\text {nd }}$ slice was consumed 4 hours later at lunchtime (13.00 hrs).

\section{Week 2}

Bread was administered to subjects (Regime B) supplying a total of $200 \mu \mathrm{g}$ of folic acid in 2 slices over a period of 7 days. The $1^{\text {st }}$ slice was consumed each day at breakfast time (09.00 hrs) and the $2^{\text {nd }}$ slice was consumed 4 hours later at lunchtime (13.00 hrs).

\section{Week 3}

Bread was administered to subjects (Regime A) supplying a total of $100 \mu \mathrm{g}$ of folic acid in 2 slices over a period of 7 days. The $1^{\text {st }}$ slice was consumed each day at breakfast time (09.00 hrs) and the $2^{\text {nd }}$ slice was consumed 4 hours later at lunchtime (13.00 hrs).

Between weeks 1, 2 and 3 subjects consumed a $400 \mu \mathrm{g}$ supplement daily for 7 -days in an attempt to re-saturate total serum folate levels.

\section{Blood collection}

On day 7 of each bread regime (A, B and C) the subjects were asked to come to the laboratory at 8 am having fasted from the folic acid fortified bread since the previous lunchtime. Hence approximately 20 hours had lapsed since their last intake of folic acid. An intravenous cannula was inserted and a pre-prandial serum sample (i) was collected for unmetabolised folic acid and serum folate from each subject. This sample was collected in order to establish a pre-prandial baseline before each of the bread regimens. The first slice of bread was then administered. Serum samples were collected every hour for 4 hours (samples ii, iii, iv and v). The second slice of bread was

Time line (weeks)

\begin{tabular}{lll|l|l|l|l|l|}
\hline 0 & 10 & 14 & 15 & 16 & 17 & 18 & 19
\end{tabular}

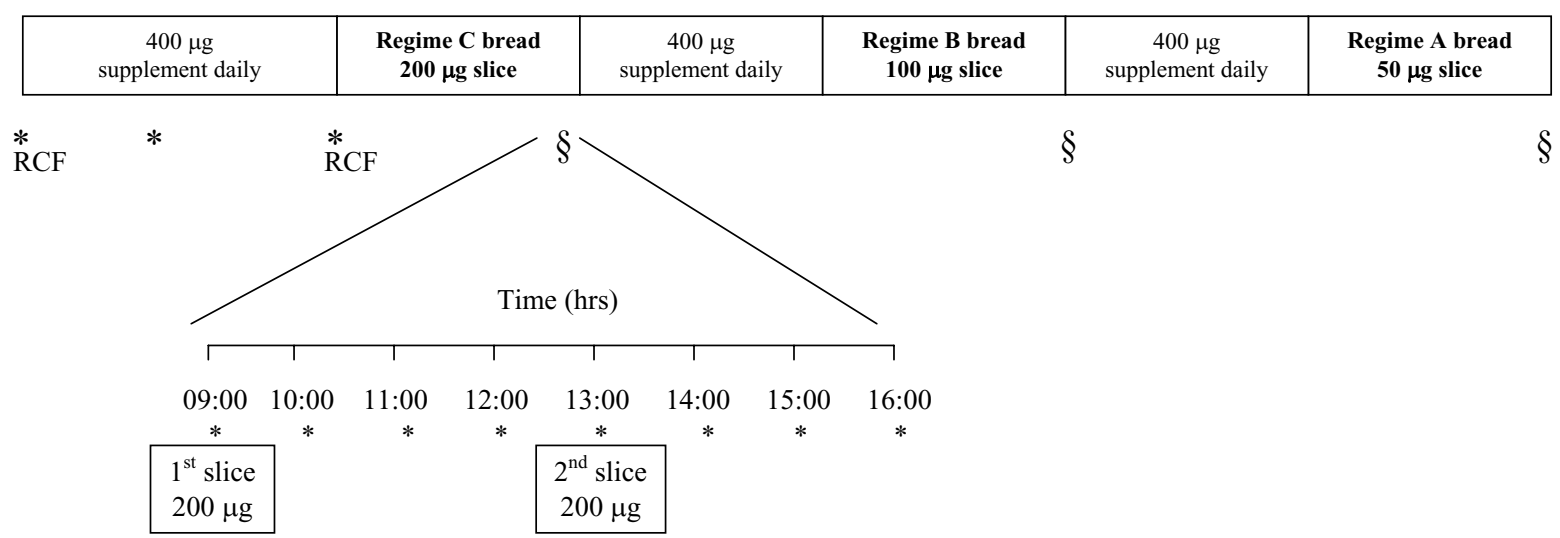

Figure I

This flow diagram illustrates diagrammatically the interventions and sampling points. Schematic summary of intervention phases and sample collection. * = Folate and Folic Acid blood sample. RCF = Red cell folate blood sample. $\S=$ Day 7 , trial of bread regimes $(200 \mu \mathrm{g}, 100 \mu \mathrm{g}, 50 \mu \mathrm{g})$. 
Table I: Mean red cell $(\mu \mathrm{g} / \mathrm{L})$ and serum folate $(\mu \mathrm{g} / \mathrm{L})$ concentrations at recruitment $(\mathbf{n}=19)$.

\begin{tabular}{cccc}
\hline & Serum folate & Red cell folate & Folic acid \\
Mean & 7.60 & 477.97 & 0.00 \\
SD & 4.25 & 173.99 & $-\cdots--$ \\
Cl (95\%) & $5.55-9.65$ & $364.10-531.83$ & --- \\
\hline
\end{tabular}

This table illustrates mean baseline red cell $(\mu \mathrm{g} / \mathrm{L})$ and total serum folate concentrations $(\mu \mathrm{g} / \mathrm{L})$ at recruitment $(n=19)$. No subjects had detectable serum folic acid at baseline $(>0.312 \mu \mathrm{g} / \mathrm{L})$.

Normal reference range for red cell folate is in the range of $150-1000 \mu \mathrm{g} / \mathrm{L}$ and for total serum folate is $2.7-20 \mu \mathrm{g} / \mathrm{L}$

then administered and serum samples were collected every hour for 3 hours (samples vi, vii and viii). It was thought that this pattern would give a good overall picture of the appearance (if present) of unmetabolised folic acid and of the duration of its presence.

\section{Laboratory analysis}

All samples were assayed for total serum folate and red cell folates by the L. casei microbiological assay described by [24]. Analysis of samples for unmetabolised folic acid was carried out by HPLC separation of the folic acid followed by solid phase extraction [4]. The re-suspended folic acid was quantified by the L. casei microbiological assay above. The lower limit of detection of the assay was calculated to be $0.3125 \mathrm{ng} / \mathrm{ml}$.

\section{Statistical Analysis}

Statistical analysis was performed using the computer package Data Desk 5.0. Repeated measures anova was used when comparing serum folic acid/total folate concentrations at one time point with serum folic acid/total folate concentrations at another time point. Post Hoc Scheffe tests were employed to compare serum folic acid/ total folate concentrations at multiple sampling points.

\section{Results}

\section{Intervention phase I}

Baseline red cell and serum folate concentrations were within normal reference ranges for all subjects (Table 1). Unmetabolised folic acid was not detected in any of the baseline samples collected at week 0 (Table 1). Serum folate concentrations increased significantly from week 0 to week 14 after the supplementation regime $(\mathrm{p}<0.001)$ ) as did red cell folate concentrations ( $\mathrm{p}<0.001)$ (table 2$)$.
At week 14, 6-hours after consumption of the $400 \mu \mathrm{g}$ supplement unmetabolised folic acid was present in the sera of 18 subjects $(n=19) .7$ of these 18 subjects demonstrated only slightly elevated folic acid levels, which were calculated to be below the level of that which is accurately quantifiable. Nonetheless the difference between week 0 and week 14 was statistically significant $(\mathrm{p}<0.001)$ demonstrating that the supplementation did give rise to an elevated folic acid level, which was still detectable six hours after it had been consumed (Table 2).

\section{Intervention- phase II}

Unmetabolised folic acid was present in the sera of 17 subjects $(n=19)$ on day 7 of regime $C$ bread pre-prandially (sample i). All of these were above the lowest limit of quantification and were statistically different from week 14 levels ( $<<0.001)$ (see figure 2). Unmetabolised folic acid levels increased post-prandially in all subjects after consumption of the first slice of bread containing $200 \mu \mathrm{g}$ folic acid ( $p<0.001)$ (figure 2). It was also present in the sera of all subjects after the $2^{\text {nd }}$ slice containing a further $200 \mu \mathrm{g}(\mathrm{p}<0.001)$ (figure 2).

Post hoc analysis showed that differences in serum folic acid were significant between samples $i$ and samples ii ( $p$ $<0.001)$, samples $i$ and samples iii $(p<0.001)$, samples $i$ and samples vi $(\mathrm{p}<0.001)$ and samples $i$ and samples vii $(p<0.001)$. An accumulative elevation of unmetabolised folic acid was demonstrated in 12 out of 19 subjects after the $2^{\text {nd }}$ slice (see figure 2). Unmetabolised folic acid was not detected in the sera of any of the subjects on day 7 of regime B or A bread pre- or post-prandially (tables 3 and 4).

Table 2: Mean red cell folate $(\mu \mathrm{g} / \mathrm{L})$, total serum folate $(\mu \mathrm{g} / \mathrm{L})$ and unmetabolised folic acid $(\mu \mathrm{g} / \mathrm{L})$ concentrations at week- I $4(\mathrm{n}=19)$.

\begin{tabular}{cccc}
\hline Subjects & Serum folate & Red cell folate & Folic acid \\
\hline Mean & 14.77 & 693.94 & 0.21 \\
SD & 5.01 & 198.72 & 0.16 \\
Cl (95\%) & $12.38-19.22$ & $434.87-903.49$ & $0.29-0.52$ \\
\hline
\end{tabular}

This table illustrates mean red cell folate $(\mu \mathrm{g} / \mathrm{L})$, total serum folate and unmetabolised folic acid $(\mu \mathrm{g} / \mathrm{L})$ concentrations after consuming a $400 \mu \mathrm{g}$ folic acid supplement daily for 14 weeks $(n=19)$. 6 subjects had detectable folic acid levels $(>0.312 \mu \mathrm{g} / \mathrm{L})$.

Normal reference range for red cell folate is in the range of $150-1000 \mu \mathrm{g} / \mathrm{L}$ and for total serum folate is $2.7-20 \mu \mathrm{g} / \mathrm{L}$ 


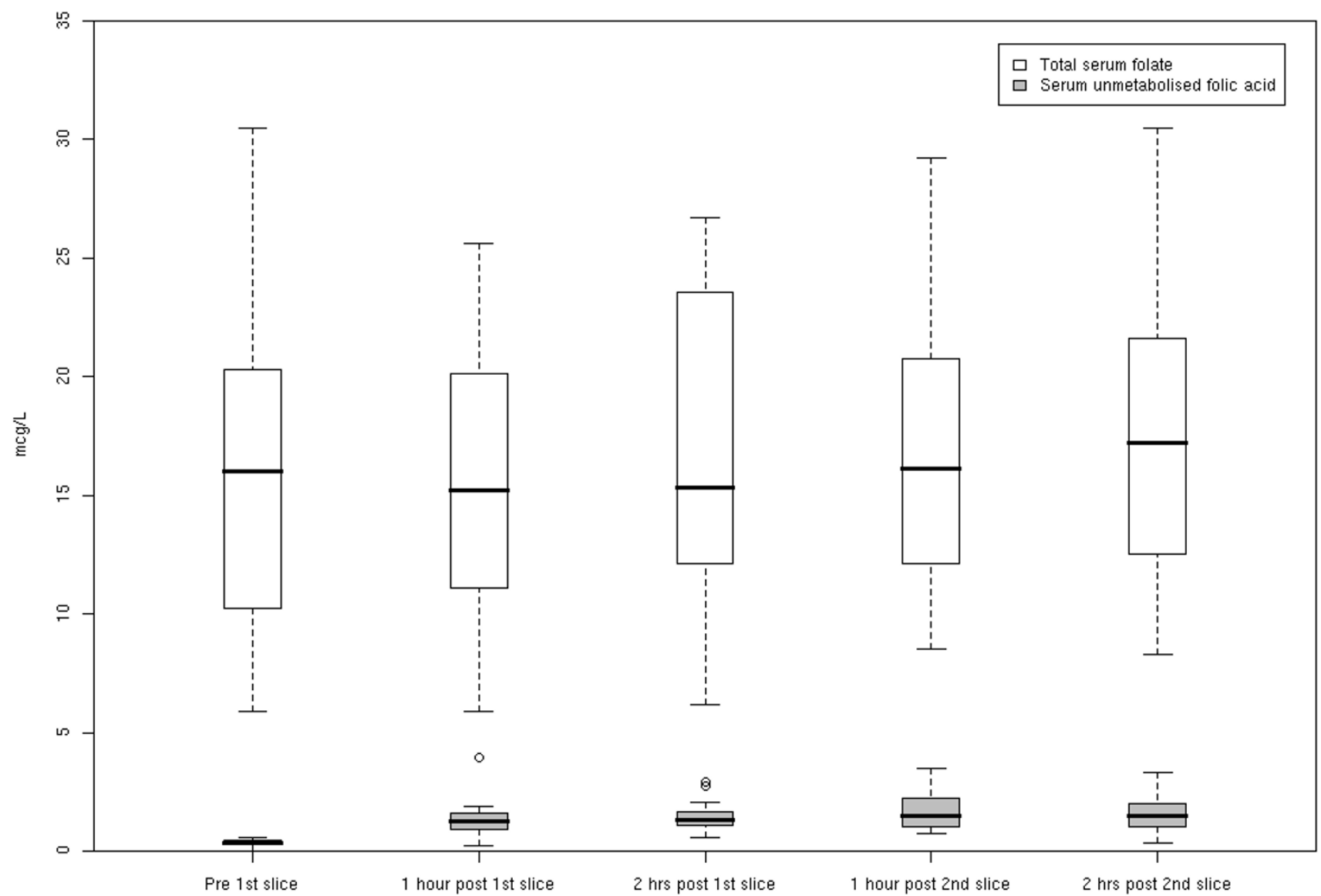

Figure 2

Mean total serum folate $(\mu \mathrm{g} / \mathrm{L})$ and mean serum unmetabolised folic acid $(\mu \mathrm{g} / \mathrm{L})$ pre and post regime $C$ bread $(\mathbf{n}=19)$. This graph illustrates mean total serum folate $(\mu \mathrm{g} / \mathrm{L})$ and mean serum unmetabolised folic acid $(\mu \mathrm{g} / \mathrm{L})$ concentrations in a group of healthy adult subject $(n=19)$ exposed to a folic fortified bread for I-week. Subject were pre-saturated with folic acid supplements for I4-weeks prior to the bread. The bread was fortified with $200 \mu \mathrm{g}$ folic acid per slice, which was administered twice a day for seven days. The samples shown here were collected on the 7 th day of bread consumption pre-prandially and post-prandially.

Table 3: Serum folate and serum folic acid $(\mu \mathrm{g} / \mathrm{I})$. Samples collected on day 7 of regime B bread ( $100 \mu \mathrm{g}$ in each slice) pre and post prandially.

\begin{tabular}{|c|c|c|c|c|c|c|c|c|}
\hline & pre Ist slice & I hour post & $2 \mathrm{hrs}$ post & $3 \mathrm{hrs}$ post & $4 \mathrm{hrs}$ post & I hour post $2^{\text {nd }}$ slice & 2 hrs post & $3 \mathrm{hrs}$ post \\
\hline Serum folate & $\mathrm{i}$ & ii & iii & iv & v & vi & vii & viii \\
\hline Mean & $|4.1|||$ & 14.70 & 15.16 & 14.72 & $|4.4|$ & 14.43 & 13.84 & 13.28 \\
\hline SD & 5.24 & 5.59 & 4.99 & 5.32 & 5.83 & 5.78 & 5.25 & 5.47 \\
\hline $\mathrm{Cl}(95 \%)$ & $11.59-16.63$ & $12.00-17.39$ & $12.75-17.56$ & $12.16-17.28$ & $11.60-17.22$ & $11.65-17.22$ & $11.23-16.45$ & $10.46-16.10$ \\
\hline
\end{tabular}

This table illustrates mean total serum folate $(\mu \mathrm{g} / \mathrm{L})$ concentrations in a group of healthy adult subject $(n=19)$ exposed to a folic fortified bread for I-week. Subject were pre-saturated with folic acid supplements for 14-weeks prior to the bread. The bread was fortified with $100 \mu \mathrm{g}$ folic acid per slice, which was administered twice a day for seven days. The samples shown here were collected on the $7^{\text {th }}$ day of bread consumption preprandially and post-prandially. Standard deviations and confidence intervals are also shown. Serum folic acid was not detectable at any sampling points 
Table 4: Serum folate and folic acid ( $\mu \mathrm{g} / \mathrm{L})$. Samples collected on day 7 of regime A bread (50 $\mu \mathrm{g}$ in each slice) pre and post prandially.

\begin{tabular}{|c|c|c|c|c|c|c|c|c|}
\hline & pre $50 \mu g$ & I hour post & 2 hrs post & $3 \mathrm{hrs}$ post & 4 hrs post & I hour post $2^{\text {nd }}$ slice & 2 hrs post & 3 hrs post \\
\hline Serum folate & i & ii & iii & iv & v & vi & vii & viii \\
\hline Mean & 16.91 & 16.30 & 16.99 & 16.88 & 17.40 & 15.56 & 15.40 & 14.82 \\
\hline $\mathrm{SD}$ & 6.55 & 6.62 & 6.42 & 6.24 & 7.12 & 5.77 & 6.04 & 5.21 \\
\hline $\mathrm{Cl}(95 \%)$ & $13.75-20.06$ & $13.1 \mid-19.49$ & $13.89-20.08$ & $13.87-19.88$ & $13.97-20.83$ & $12.78-18.34$ & $|2.49-| 8.3 \mid$ & $12.31-17.33$ \\
\hline
\end{tabular}

This table illustrates mean total serum folate $(\mu \mathrm{g} / \mathrm{L})$ concentrations in a group of healthy adult subject $(\mathrm{n}=19)$ exposed to a folic fortified bread for I-week. Subject were pre-saturated with folic acid supplements for I4-weeks prior to the bread. The bread was fortified with $50 \mu g$ folic acid per slice, which was administered twice a day for seven days. The samples shown here were collected on the $7^{\text {th }}$ day of bread consumption preprandially and post-prandially. Standard deviations and confidence intervals are also shown. Serum folic acid was not detectable at any sampling points

Total folate concentrations did not change significantly over the 8 hours after regime $\mathrm{C}(\mathrm{P}=0.8941)$, regime $\mathrm{B}(\mathrm{P}$ $=0.9820)$ or regime A bread $(\mathrm{p}=0.8829)$ (figure 2$)$.

\section{Discussion}

Unmetabolised folic acid was not detected in any of the subjects at week 0 . It was detected in the serum of all subjects after consumption of a $400 \mu \mathrm{g}$ folic acid supplement daily for 14 weeks even though the samples were collected six-hours after the last supplement. It is likely then that women complying with the current DOH (UK) [25] recommendation to consume a $400 \mu \mathrm{g}$ supplement daily for their entire childbearing years would be exposed to unmetabolised folic acid in serum for at least six out of twentyfour hours every day. The safety implications of this are unknown but long-term surveillance of serum folic acid at a population level may be useful to observe if an accumulation occurs over time.

Out of the three fortified bread regimens administered only the highest one (400 $\mu \mathrm{g}$ administered in two equal doses) lead to the appearance of folic acid in serum. Both the first and the second slice lead to this effect and an accumulation was noted after the second one. Whether these levels would accumulate indefinitely or plateau at some point with prolonged repeated exposure in a population exposed to these levels under a fortification programme is unknown but again ongoing surveillance is indicated.

From a positive viewpoint our data shows that unmetabolised folic acid did not appear in serum after consumption of the first or second slice of bread containing either $50 \mu \mathrm{g}$ or $100 \mu \mathrm{g}$ each over a period of 1 week even after a period of pre-saturation. The latter is the amount currently supplied to the average US citizen in the US fortification programme. It is important to remember however that the level of fortification currently in place in the USA is based on FDA calculations for delivery of $100 \mu \mathrm{g}$ of folic acid at "average intakes". Folic acid in the diet from other sources other than mandatory folic acid fortified bread will of course augment these intakes, as breakfast cereals and many other foodstuffs in the United States are also fortified with folic acid, for example consumption of a couple of servings of ready-to-eat breakfast cereals and toast would easily exceed $200 \mu \mathrm{g}$ in a single dose. In addition persons complying with the recommendation to consume a $400 \mu$ g supplement daily (estimated to be 30 $40 \%$ of Americans) will have sufficient intakes to lead to unmetabolised folic acid in serum before they even consume any fortified foods.

\section{Conclusion}

Based on the cumulative evidence to date in this and other studies [4-6] it seems that the threshold dose above which unmetabolised folic acid appears in serum lies around $200 \mu \mathrm{g}$. The intervals between repeated exposures also seem to be an important factor [6] as an accumulative effect is observed if repeated doses are consumed close together. These are important considerations for policy makers planning an intervention.

\section{Competing interests}

There are no conflicts of interest for any of the authors in relation to this work. The lead authors had full access to all the data in the study and had final responsibility for the decision to submit for publication.

\section{Authors' contributions}

MRS designed and conducted the research study (both the nutrition intervention phase and the laboratory work). She also analysed and interpreted the data and drafted the manuscript.

IS had the original idea for the study and advised on all aspects of the study.

$\mathrm{JMcP}$ advised and assisted with all phases of the project

All authors read and approved the final manuscript. 


\section{Acknowledgements}

We would like to thank all the subjects who gave up their time to take part in this study.

The authors would like to thank Superquinn Bakeries, Kimmage, Dublin for baking the bread.

The authors would like to acknowledge the assistance of Dr. Anthony Staines and Mr. Andrew Boilson with the statistical analysis for the revised manuscript.

\section{References}

I. Quinlivan EP, Gregory JF: Effect of food fortification on folic acid intake in the United States. Am J Clin Nutr 2003, 77:22 I-5.

2. Oakley GP, Myron JR, Adams J, Dickinson CM: More folic acid for everyone, Now. American Institute of Nutrition; 1996:75 IS-755S.

3. Sweeney MR, McPartlin J, Weir DG, Scott JM: Measurements of subnanamolar concentrations of unmetabolised folic acid in serum. Journal of Chromotography B 2003, 788:187-191.

4. Kelly P, Mc Partlin J, Scott JM: A combined High-Performance liquid chromatographic microbiological assay for serum unmetabolised folic acid. Analytical Biochemistry 1996, 238: $179-183$.

5. Sweeney MR, McPartlin J, Weir DJ, Daly L, Scott JM: Post-prandia serum folic acid response to multiple doses of folic acid in fortified bread. $\mathrm{Br}$ J Nutr 2006, 94: I-8.

6. Sweeney MR, McPartlin J, Weir DJ, Daly S, Pentieva K, Daly L, Scott $J M$ : Evidence of unmetabolised folic acid in cord-blood of new-born and serum of four-day old infants. B/N 2005, 94:727-730.

7. Tisman G, Herbert V: B-I 2 dependence of cell uptake of serum folate: explanation for high serum folate and cell folate depletion in B-I 2 deficiency. Blood 1973, 4 I:465-9.

8. Metz J, Kelly A, Swett VC, Waxman S, Herbert V: Deranged DNA synthesis by bone marrow from vitamins B-I2 deficient humans. British Journal of Haematology 1968, I 4:572-92.

9. Zittoun J, Marquet J, Zittoun R: Effect of folate and cobalamin compounds on the deoxyuridine supression test in vitamin B-I 2 and folate deficiency. Blood 1978, 5 I: I I 9-28.

10. Ganeshaguru K, Hoffbrand AV: The effect of deoxyuridine, vitamin B - I2, folate and alcohol on the uptake of thymidine and on the deoxynucleoside triphosphate concentrations in normal and megaloblastic cells. British Journal of Haematology 1978, 40:29-4I.

II. Heinle RM, Welch AD: Folic acid in pernicious anaemia. Failure to prevent neurologic relapse. JAMA 1974, I33:739-74I.

12. Bethal $\mathrm{FH}$, Stergis CC: The relation of therapy in pernicious anaemia to changes in the nervous system. Early and late results in a series of cases observed for periods of not less than ten years, and early results of treatment with folic acid. Blood 1948, 3:57-67.

13. Ross JF, Belding H, Paegal BL: The development and progression of subacute combined degeneration of the spinal cord in patients with pernicious anaemia treated with synthetic pteroylglutamic (folic) acid. Blood 1948, 3:68-90

14. Vilter RW, Horrigan D, Mueller JF, Jarrold T, Vilter CF, Hawkins V, Seaman A: Studies on the relationships of vitamin B I2, folic acid, thymine, uracil, and methyl group donors in persons with pernicious anaemia and related megaloblastic anaemias. Blood 1950, 5:695-717.

15. Israels MCG, Wilkinson JF: Risk of neurological complications in pernicious anaemia treated with folic acid. British Medical Journal 1949:1072-1075.

16. Food and Drug Administration: Food labelling: health claims and food label statements; folate and neural tube defects. Federal Register 1996, 6 I (44):8752-807.

17. Troen AM, et al:: Unmetabolised folic acid in plasma is associated with reduced natural killer cell cytotoxicity among post-menapausal women. J Nutr 2006, I36: I89-194.

18. Stolzenberg-Solomon RZ, Chang SC, Leitzmann MF, Johnson KA, Johnson C, Buys SS, Hoover RN, Ziegler RG: Folate intake, alcohol use and postmenopausal breast cancer risk in the pros- tate, lung, colorectal, and ovarian cancer screening trial. Am J Clin Nutr 2006, 83:895-904.

19. Kim Young-In: Will mandatory folic acid fortification prevent or promote cancer. American Journal of Clinical Nutrition 2004, 80(5): I I23-I I 28

20. Charles D, Ness AR, Campbell D, Smith GD, Hall MH: Taking folate in pregnancy and risk of maternal cancer. British Medical Journal 2004, 329:1375-1376.

21. Lucock M, Yates Z: Folic acid - vitamin and panacea or genetic time bomb? Nat Rev Genet 2005, 6:235-240.

22. Sweeney MR: Folic Acid Fortification of Flour: Determination of the level that gives rise to unmetabolised folic acid in serum. In Ph D thesis Trinity College, Republic of Ireland; 2000.

23. Ward M, McNulty H, McPartlin J, Strain JJ, Weir DG, Scott JM: Plasma homocysteine, a risk factor for cardiovascular disease, is lowered by physiological doses of folic acid. Quarterly Journal of Medicine 1997, 90:519-524.

24. Molloy A, Scott JM: Microbiological assay for serum, plasma and red cell folate using cryopreserved microtitre plate method. Methods in Enzymology 1997, 281:43-53.

25. Department of Health: Folic acid and the prevention of Neural Tube Defects. In Report from an Expert Advisory Group London: Department of Health; 1992.

\section{Pre-publication history}

The pre-publication history for this paper can be accessed here:

http://www.biomedcentral.com/1471-2458/7/41/prepub
Publish with Bio Med Central and every scientist can read your work free of charge

"BioMed Central will be the most significant development for disseminating the results of biomedical research in our lifetime. "

Sir Paul Nurse, Cancer Research UK

Your research papers will be:

- available free of charge to the entire biomedical community

- peer reviewed and published immediately upon acceptance

- cited in PubMed and archived on PubMed Central

- yours - you keep the copyright 